\title{
化学物質曝露と子どもの健康との関連に関する研究動向
}

\author{
岩井 美幸 ${ }^{1}$, 中山 祥嗣 ${ }^{1}$, 磯部 友彦 ${ }^{1}$, 小林 弥生 ${ }^{1}$, 鈴木 岡 $^{1}$, 野村 恭子 ${ }^{2}$ \\ ${ }^{1}$ 国立環境研究所環境リスク・健康研究センター \\ 2 秋田大学大学院医学系研究科公衆衛生学講座
}

\section{Investigation of the Effects of Exposure to Chemical Substances on Child Health}

\author{
Miyuki IWAI-SHIMADA ${ }^{1}$, Shoji F. NAKAYAMA ${ }^{1}$, Tomohiko ISOBE ${ }^{1}$, Yayoi KOBAYASHI ${ }^{1}$, \\ Go SUZUKI ${ }^{1}$ and Kyoko NOMURA ${ }^{2}$ \\ ${ }^{1}$ Center for Health and Environmental Risk Research, National Institute for Environmental Studies \\ ${ }^{2}$ Department of Public Health, Akita University Graduate School of Medicine
}

\begin{abstract}
There is mounting concern about the effects of early-life exposure to chemical substances on children's health and development. We summarize the past and ongoing birth cohort studies carried out worldwide on the association between environmental exposure and children's health. Our PubMed search with the keywords 'birth cohort' revealed that the number of articles jumped from 200-300 in the 1980s to over 1,000 in the 1990s. Many of these articles reported elevated risks to children's health posed by chemical exposure owing their vulnerability. At the same time, policies implemented to reduce exposure to lead and dioxins were successful in the past few decades. Research also demonstrated that intervention to reduce exposure to certain chemicals whose exposure routes were well documented was also successful. We summarize the effects of early-life exposure to chemical substances on children's health and development. Our findings will hopefully help safeguard the environment in which future generations grow and live.
\end{abstract}

Key words: birth cohort（出生コホート), exposure（曝露), chemical exposure（化学物質曝露）, child health (子ぞもの健康)

1.はじめに

私たちは日常生活のなかで，多種多様な化学物質の曝 露を受けている。曝露媒体として, 食事, 水, 空気, た ばこ煙（主流煙，副流煙），八ウスダスト，日用品など が想定され，曝露経路も経口，経皮，吸入など多岐に抒 よぶ。様々な化学物質が食事，水，空気あるいは日用品 などに含まれ，その摂取あるいは使用等を通して，生涯

受付 2018 年 8 月 5 日，受理 2018 年 10 月 5 日

Reprint requests to: Miyuki IWAI-SHIMADA

Center for Health and Environmental Risk Research, National Institute for Environmental Studies, 16-2 Onogawa, Tsukuba, Ibaraki 305-8506, Japan

TEL: +81(29)850-2796

E-mail: iwai.miyuki@nies.go.jp
にわたって継続的に曝露される状況にある（1）。このよ らな曝露に対して, 特に胎児期や乳幼児期は, その影響 が懸念される時期である。これまでに図 1 に示すよらな 健康影響 [妊娠するまでの時間（妊孕力）: time to pregnancy (2)，流産：miscarriage 拈よび早産： preterm $\operatorname{birth}(3-5)$, 先天異常: birth defects $(4,6,7)$, 低出生体重: low birth weight $(4,5,8,9)$ ，精神神経発達影響 : neurodevelopmental disorders $(5,10)$, 内分泌かく乱作用: endocrine disruption (11)，性比：sex ratio(12) ] と胎児期 あるいは乳幼児期の化学物質曝露との関連が報告されて きた。また Landrigan ら（13）は, Global Burden of Disease Study 2015 の中で，様々な環境污染による死亡リスクを 算出し，その中でも大気污染によるリスクが大きいこと を示した。WHO 2012 でも同様の試算がなされている （表 1)。また Landrigan らは，死亡時の年齢階層別に障 


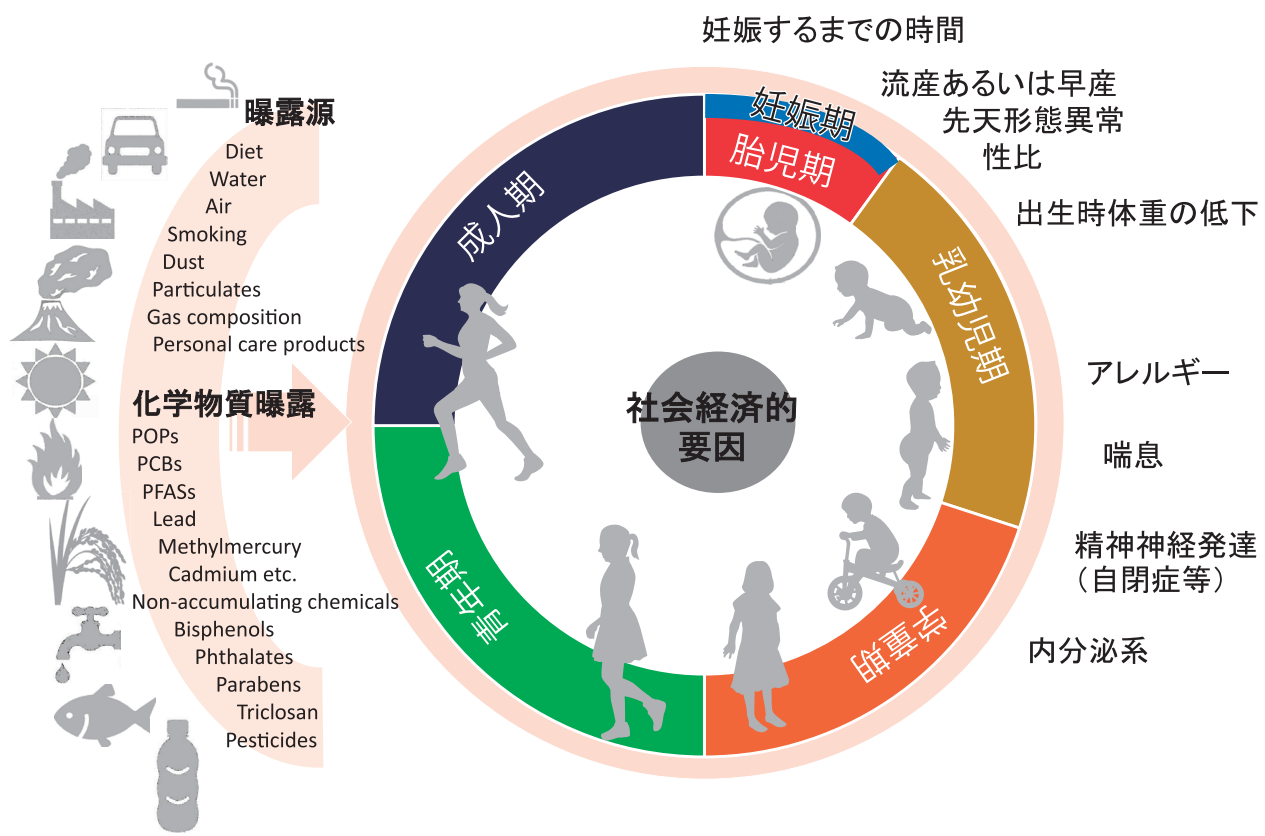

図 1 化学物質曝露とライフステージごとの有害事象との関連。POPs (Persistent Organic Pollutants : 残留性有機污染物質), PCBs (polychlorinated biphenyls : ポリ塩化ビフェニル), PFAS (perfluoroalkyl substances : 有機フッ素化合物)

表 1 Global Burden of Diseases study（GBD: 2015）におけ る環境污染リスクファクターによるグローバル推定死亡数 (Global estimated death)

\begin{tabular}{lcc}
\hline & $\begin{array}{c}\text { Global estimated } \\
\text { death (million) }\end{array}$ & $\begin{array}{c}95 \% \mathrm{CI} \\
\text { (million) }\end{array}$ \\
\hline 空気 & 6.5 & $5.7-7.3$ \\
水 & 1.8 & $1.4-2.2$ \\
職業上 & 0.8 & $0.8-0.9$ \\
土壌, 重金属, 化学物質 & 0.5 & $0.2-0.8$ \\
鉛 & 0.5 & $0.2-0.8$ \\
\hline 全体 & 9.0 & \\
\hline
\end{tabular}

Landrigan et al., Lancet (2018), p. 462-512, The Lancet Commission on pollution and health(13) を改変

害調整生命年（disability-adjusted life year: DALY）に対 する環境污染の負荷を試算し, 乳幼児期は他の年代と比 べると推定された DALY が大きく，子どもの脆弱性を 指摘した。本稿は, 2018 年 3 月の第 88 回日本衛生学会 学術総会で開催された「少子高齢化社会日本に打ける学 術研究からの問題提起」シンポジゥムで発表した内容に 加え，化学物質を対象とした出生コホート調査に関する 報告とその影響についてょり詳細に解説し，整理したも のである。

\section{2. 化学物質を対象とした世界各地のコホート調査}

文献データベースPubMedを用いて，"birth cohort" といらキーワードで検索すると，75,087 件が抽出された (2018 年 7 月 30 日現在)。図 2 は, 1980 年代から現在に
至るまでの PubMed で抽出された論文数を年ごとに示し ている。1980年代前半では, “birth cohort”いらキーワー ドで抽出される論文数は年に $200 〜 300$ 報程度であった が, 1990 年代に入ると年に 1,000 報を超すようになった。 2017 年には年 5,231 報もの論文が登録され, 出生コホー 卜調査といら研究スタイルが広く世界各地で実施されて いることがうかがえる。また, “birth cohort”に “exposure” といらキーワードを追加して検索した場合, 出生コホー 卜調査研究の発表数の増加にともなって曝露を扱う論文 数も増加する（必ずしも化学物質曝露だけが対象となっ ていない)。具体的には，1980 年代には年に 10～20 報 程度であった論文数が，1990 年代後半には年に 100 報 を超し，2017 年には年 724 報になった。これにはオー プンアクセスジャーナルの広がりといった雑誌数自体の 数が増えたことも推察されるが (14), 出生コホート調 査に打いて様々な曝露を評価する重要性が認識されたこ とを反映していると考兄られる実際，1980年から 2018 年末でについて，10 年ごとに “birth cohort”で検 索される論文数に占める “exposure”の論文数の比をと り，その平均割合をみてみると，1980 年代 4\%，1990 年代 $8 \%, 2000$ 年代 $10 \%, 2010$ 年代 $12 \%$ と, 徐々にそ の割合が上昇して打り，“birth cohort”执よび “exposure” といった視点の研究に，世界中の研究者が重点を置いて いることが示唆される。これら報告の多くは，子どもの 健康リスクが増加しているのではないかという懸念, あ るいは様々な曝露に対する小览の脆弱性への関心のあら われである。

こうした背景の中, 過去あるいは現在進行中の化学物 質を対象とした出生コホート調査事例について，サンプ 


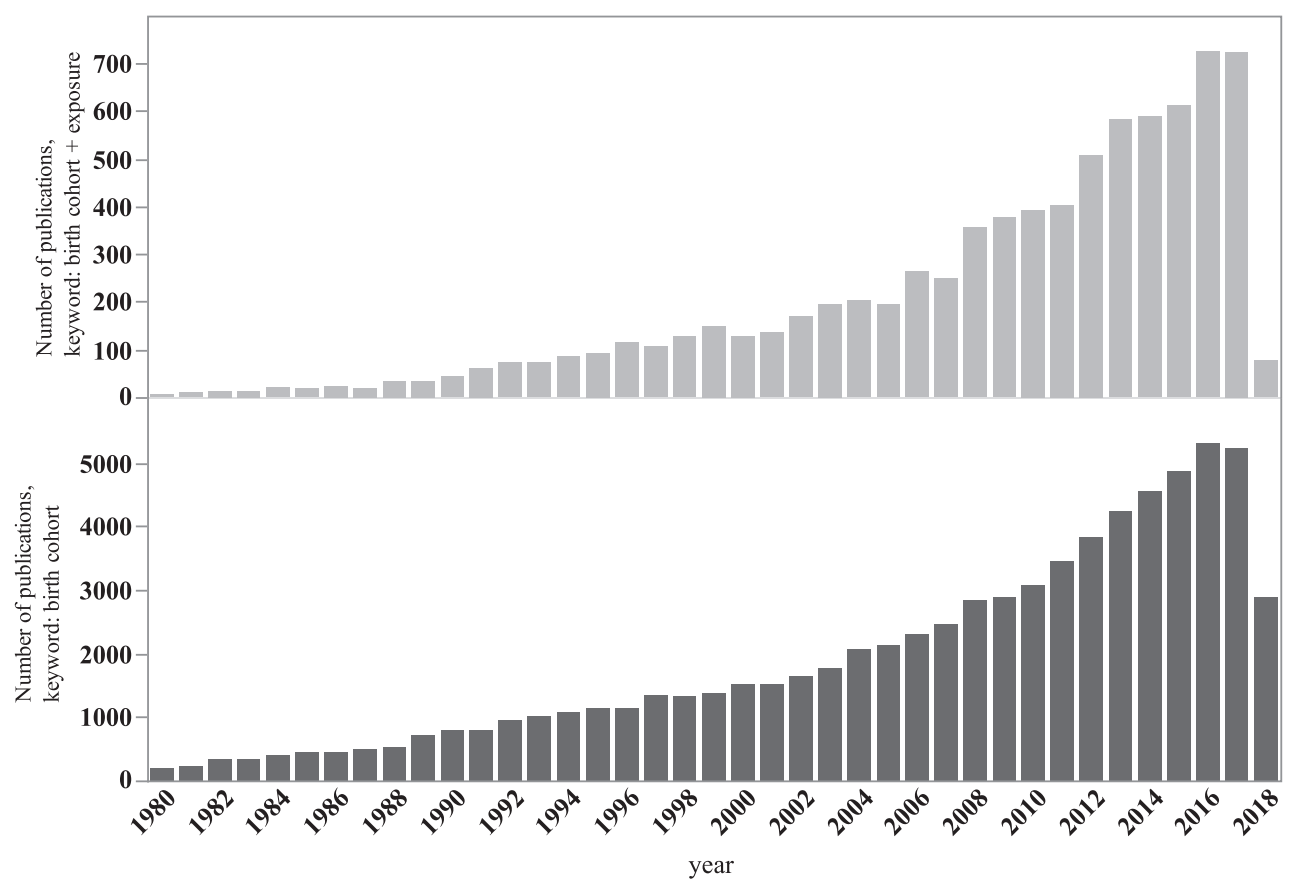

図 2 PubMed での birth cohort (下段)，あるいは birth cohort + exposure（上段）をキーワードとした際の年別論文数の推移（2018 年 7 月 30 日現在)

ルサイズ, 評価対象物質, 分析試料, 対象アウトカム括 よび対象地域等を表 2 に整理する。国内で進行している コホート調査として Japan Environment and Children's Study（JECS）は，環境省事業として全国 10 万組の親 子が参加する大規模な疫学調査「子ぞもの健康と環境に 関する全国調査 (エコチル調査)」であり，2011年より実 施されている。5つの領域 (妊娠 - 生殖, 先天異常, 精神 神経発達, 免疫・アレルギ一, 代謝・内分泌）と金属類, polychlorinated biphenyls (PCBs), perfluoroalkyl substances (PFASs) 等の POPs (Persistent Organic Pollutants), 農薬, フェノール類およびフタル酸類等の化学物質曝露, 大気 污染, 生活環境あるいは社会経済状況との関連について の研究が進められている(15)。Hokkaido Study（北海道 スタディ）は，環境と子どもの健康に関する研究として 2002 年より進められている。先天異常（特に尿道下裂, 停留精巣）のリスク要因, 出生体重あるいは神経発達と 内分泌かく乱物質（ダイオキシン類, PCBs, PFASs 等の POPs，フタル酸エステル類等）との関連について報告 されている $(16,17)$ 。Tohoku Study of Child Development は, 東北コホート調査として 2001 年より進められ, 出生 体重あるいは神経発達とメチル水銀, PCBs あるいは鉛 との関連について報告されている（18-20）。その他, メ チル水銀の胎児期曝露影響に関して, 重要な知見をもた らした Seychelles Child Development Study, Faroese Birth Cohort 拈よびNew Zealand Study(21), PCBs 等の POPs 曝露影響として Dutch PCB/Dioxin Study(22), Oswego Newborn and Infant Development Project(23), Michigan Cohort 抒よび North Carolina Cohort (24), 鉛の曝露影響
として Port Pirie Cohort, Cincinnati Lead Study Cohort, Boston Birth Cohort(25), Mexico City Prospective Lead Study(26) 抒よび Rochester Longitudinal Lead Study(27) などが挙げられる。これらのコホート調査は, 規模は小 さいが, その研究成果は現在の出生コホート調査拉よび リスク評価の礎となっている。また, 2000 年以降アジ アで非常に多くの出生コホート調査がはじまり, 例とし て, 中国では Laizhou Wan Birth Cohort, Nanjing Medical University Birth Cohort 执よび Shanghai Birth Cohort, 韓 国では Environment and Development of Children Study, The Mothers and Children's Environmental Health Study fo よび Panel Study on Korean Children 等, マレーシアでは Universiti Sains Malaysia Pregnancy Cohort Study, ネパー ルでは Nepali Birth Cohort Study in Chitwan Valley, フィ リピンでは Cebu Longitudinal Health and Nutrition Survey, 台湾では Taiwan Maternal and Infant Cohort Studyなどが あり，サンプルサイズも数百から数万まで多彩で非常に 多くの出生コホートが進められている (17)。サンプル サイズの大きい国家規模のプロジェクトとしてェコチル 調査（15）の他に，ノルウェーの Norwegian Mother and Child Cohort Study(28), デンマークの Danish National Birth Cohort(29) 扎よび韓国の Korean Children's Environmental Health Study が進行中である。ノルウェーが 9 万 人 (1999 年より開始), デンマーク（1997 年より開始） 扣よび韓国（2015 年より開始）が日本と同じ 10 万人規 模である。ノルウェーでは妊娠, 低体重, 先天形態異常, 喘息, アレルギー, 糖尿病, 癌, 自閉症等をアウトカム とし, 感染, 栄養, 職業抢よびライフスタイル（アルコー 


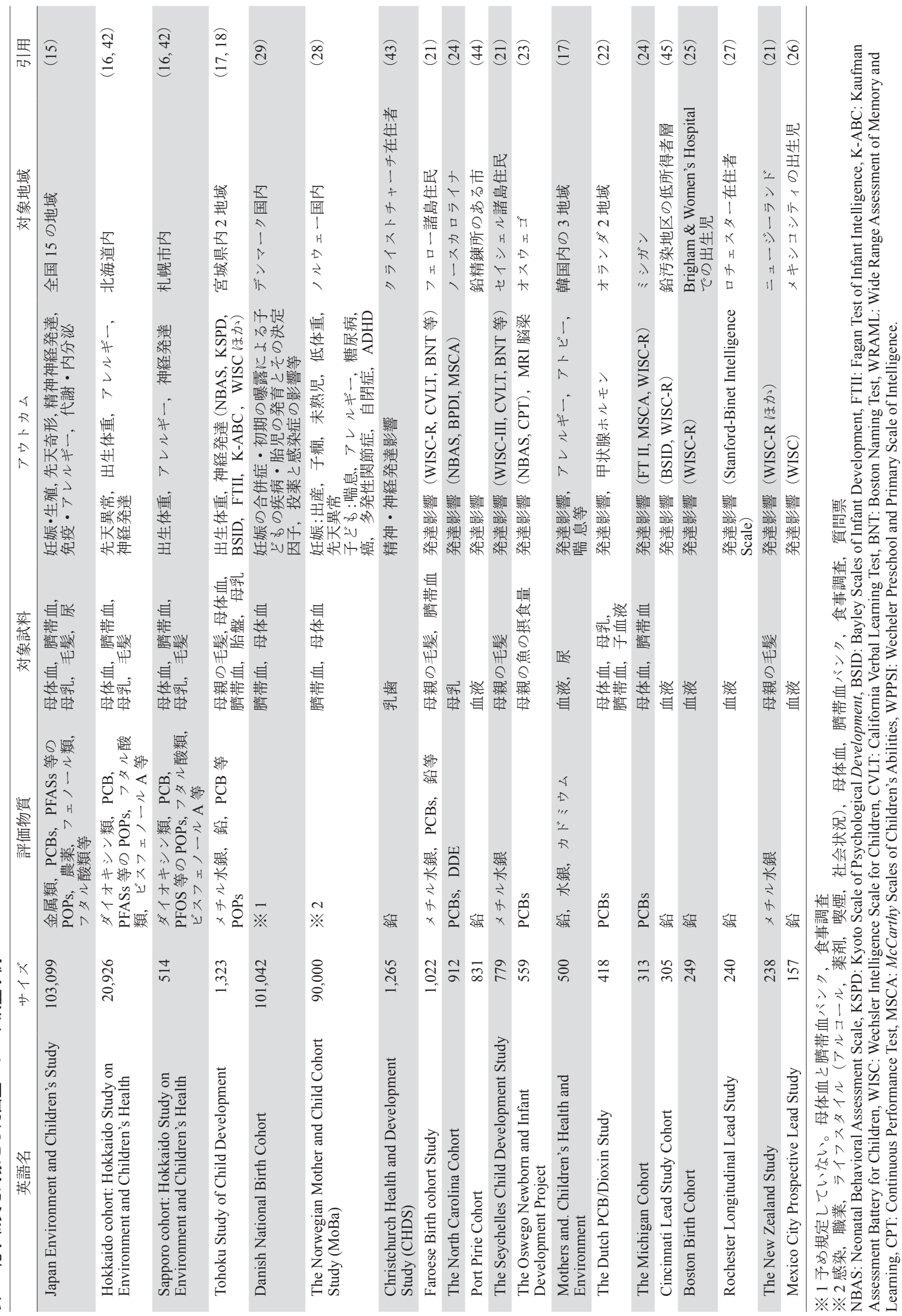


ル, 契煙および社会状況等）を主な曝露要因として調査 を進め, 母体血, 臍帯血のバンキングも実施される。デ ンマークでは, 妊娠合併症, 初期の曝露による子ぞもの 疾病抒よび胎児の発育をアウトカムとし進めている。こ こでは特定の曝露を予め規定せず，母体血と臍帯血のバ ンキングも実施される。これら大規模な出生コホート調 査は, 2000 年前後以降に開始された比較的新しい調査 である。発生頻度の少ない疾病や複数の懪露影響を評価 する上で重要であり, 成果に至るまでの道のりは長いも のの, 得られる成果は大きい。

\section{3. 胎児期・乳幼児期の化学物質曝露と 関連が報告されたアウトカム}

表 3 では, 胎児期・乳幼児期の曝露および現在の曝露 (current exposure) に分け，関連が報告されたアウト カムを整理した。なお，Children's Healthの特集をし ていることから，2010 年以降に Environmental Health Perspectives 発表さ机た論文の久を対象とした。ここで 示したように，近年でも金属類，POPs，農薬，フェノー ル類あるいはフタル酸エステル類なぞの胎児期・乳児期 曝露との関連が報告されていた。これらの物質の影響は 多岐にわたり, 妊孕力, 先天異常, 精神神経発達（ADHD: Attention-deficit hyperactivity disorder, LD : Learning disability 抽よび自閉症あるいは IQ : Intelligence quotient への影響なぞ), 内分泌かく乱作用, 肥満㐨よび免疫・ アレルギーに関するものなどが報告されている。また胎 览期・乳児期の化学物質曝露と成人以降のアゥトカムと の関連を解析した報告もあり, 長期的な追跡の必要性を 示唆している。胎児期・乳児期の曝露のみならず, 物質 によっては現在の曝露との関連も報告され, 適切な曝露 評価のために，どの媒体（血液や尿なぞ）をいつ（胎児 期, 乳児期など）採取するべきか, 評価対象物質ごとに 十分検討する必要がある。さらに, 論文化されるデータ は, 注とんどが曝露と影響に関連性の認められた場合の みに限られて和り, 関連性が認められない場合について は結果が公表されないことが多い (publication bias)。こ のように関連がみられなかった場合についても, 本当に 影響が無いのか, それとも想定外の交絡要因等により影 響が観察されなかったのか，曝露レベルが低かったのか など，注意深く取り扱う必要がある。大規模出生コホー 卜調査のもら一つの特徵として, サンプルサイズが大き くなると検出力があがることから, 大規模出生コホート 調査で関連がみられなければ, 結果の確実性が高くなる。 一方で標本サイズが極端に大きいと, 対立仮説の帰無仮 説からの隔たりがわずかでも検出力が高くなりすぎるこ とも指摘されており, 検定結果だけでなく, 効果の大き さ (オッズ比や回帰係数等), 信頼区間なぞ指標も参考 そ結果を解釈していくべきとされている(30)。

\section{4．曝露源対策によって低減がみられた事例}

\section{4-1. 鉛}

鉛は，加工しやすく古くから利用されてきた金属の一 つで，生体に有害な金属であり，低濃度であっても子ど もに対するIQ 低下等の精神神経発達影響が報告されて いる $(31,32)$ 。これまでに, 有鉛ガッリンの廃止, 鉛水 道管の切り替学など曝露削減の取り組みがなされてい る。図 3 亿米国の年代ごとの血中鉛濃度, ガソリン中鉛 使用の関係を示す。折孔線は米国のデータであるが，ガ ソリン中鉛の使用の低下とともに血中鉛濃度が低下して いる (13)。1970 年代に米国, EU で無鉛ガリリンへの 移行が進み, 日本でも 1975 年にレギュラーガソリン, その後八イオクガソリンへの鉛の添加が禁止され，それ 以降は急激に大気中の濃度が減少していることが報告さ れている(33)。多くの先進国で，有鉛ガりリン廃止と 環境污染改善の結果, 国民の血中鉛濃度を劇的飞減少し たと考えられる(34)。このような環境政策によって, 一般人の血中鉛は低濃度になったものの, より低い濃度 レベルでも胎児期扔よび現在の曝露による子ぞもへの精 神神経発垟（特に IQ）への影響が報告され，さらなる 曝露源対策が課題である。

\section{4-2. ダイオキシン類}

ダイオキシン類は, 残留性有機污染物質に関するス トックホルム条約（POPs 条約）に含まれる物質であり, 環境中での残留性, 生物蓄積性, 人や生物への毒性が高 く, 長距離移動性が懸念される残留性有機污染物質 (POPs) である。POPs 条約では, これら POPs に対して, 製造及び使用の廃絶・制限，排出の削減，さらに，これ らの物質を含む廃棄物等の適正処理等を規定している。 環境省では，国民のダイオキシン類の懪露を低減するた めに, ダイオキシン類対策特別措置法の施行, 焼却施設 の改善, 廃棄物の十分な管理を進めるとともに,「ダイ オキシン類の人への蓄積量調査」(平成 $14 \sim 22$ 年度), 「ダ イオキシン類をはじめとする化学物質への人へのばく露 量モニタリング調査」(平成 23 年度) 及び「化学物質の 人へのばく露量モニタリング調査」(平成 $24 \sim 28$ 年度) なぞのバイオモニタリング事業を進めてきた（35）。当 該調查で公表されている 2002 年から 2015 年の血中ダイ オキシン類の各年の中央値 (pg-TEQ/g-lipid) 及び食事 由来ダイオキシン類摂取量中央値 $(\mathrm{pg}-\mathrm{TEQ} / \mathrm{kg}$ 体重/日) と, 環境省環境調査平成 27 年度報告書 (36) の大気中 $\left(\mathrm{pg}-\mathrm{TEQ} / \mathrm{m}^{3}\right)$, 水質 $(\mathrm{pg}-\mathrm{TEQ} / \mathrm{L})$ のダイオキシン類測定 結果を, 年度ごとに図 4 亿示した。各年度は調査地域, 調查対象者は異なるが，近似曲線を見る限り徐々にその 曝露レベルは低下していると考兄られる。一方で, 環境 調查平成 27 年度報告書では大気や水質以外飞土䁃も調 查しており, 濃度の減少傾向が認められなかったことが 今後の課題とされている。しかしながら，全体としては 上述の通り, ダイオキシン類対策特別措置法の施行など 


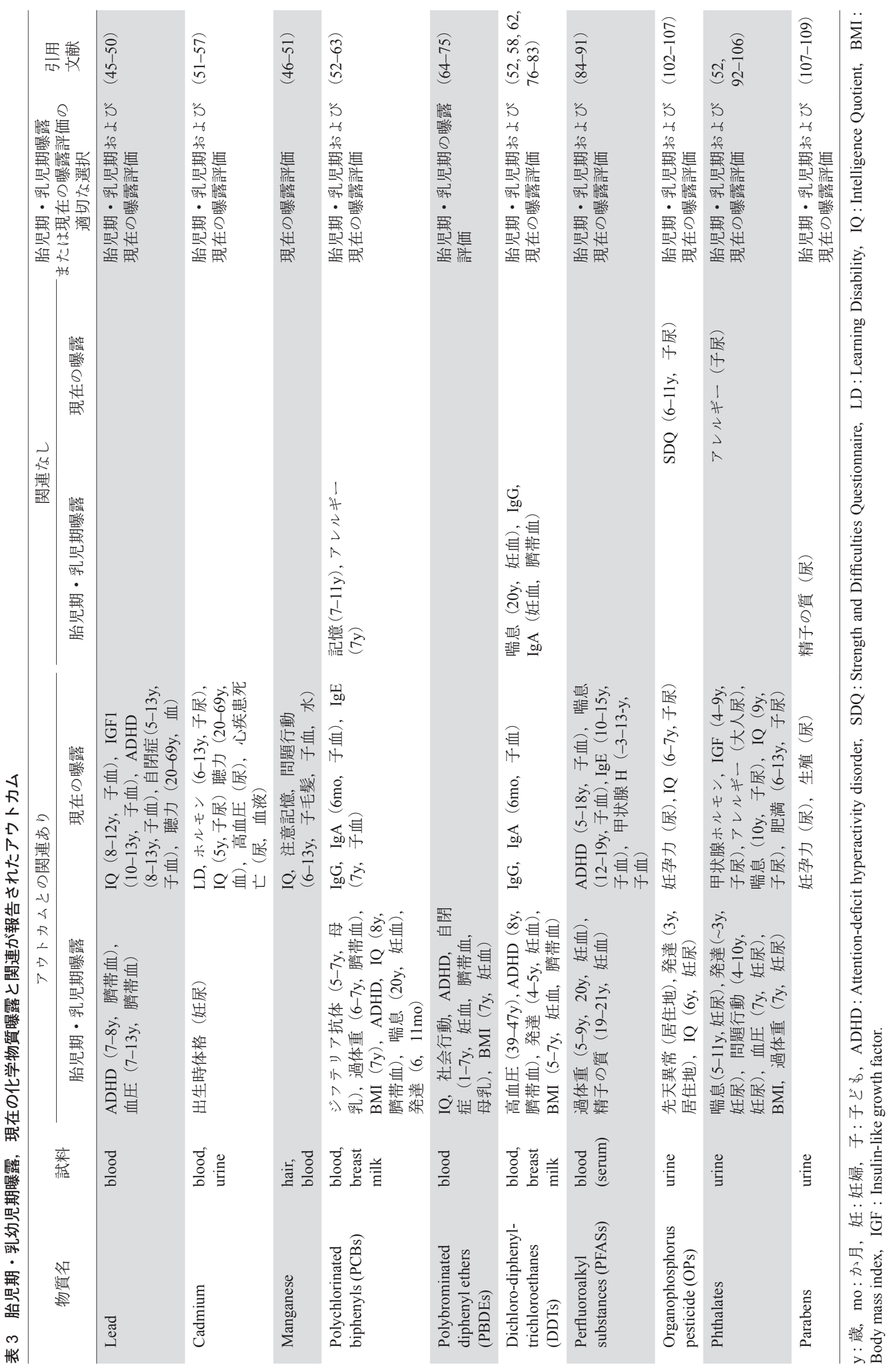




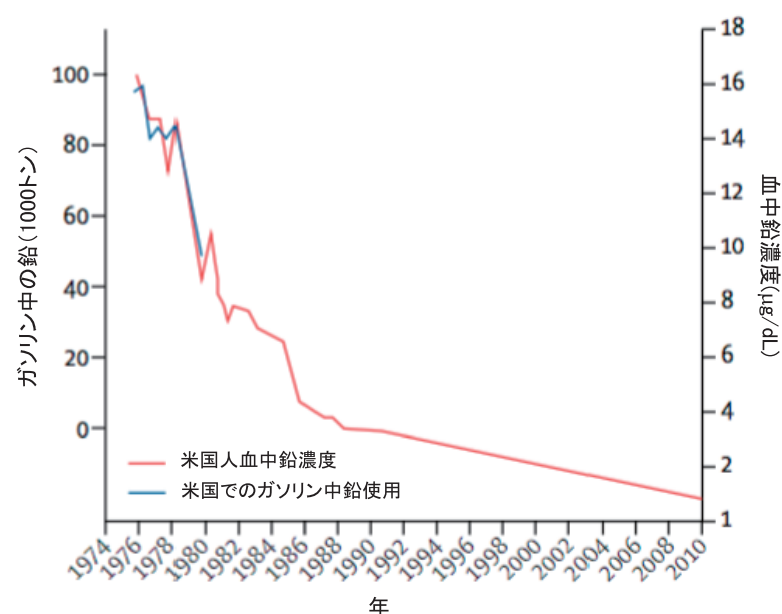

図 3 米国の年代ごとの血中鉛濃度の推移。折れ線は血中鉛濃 度 (折孔線: 赤), 米国ガソリン中鉛 (折孔線: 青) を示す。 Landrigan et al., Lancet (2018), p. 462-512, The Lancet Commission on pollution and health を転載（13）。

の環境政策によって国民の曝露は低減しており，行政に よる環境政策の良好事例といえる。ただし, ここではあ くまで曝露の低減に貢献したといら観点で紹介してお り, 曝露レベルと健康影響の関連や, 基準值の根拠とな る曝露シナリオ・エンドポイントについては, 別途議論 の余地がある。

\section{4-3. 曝露源が明らかな場合の研究的介入による曝露リ スクを最小限にする取り組み}

本項ではメチル水銀を対象とし, 研究的介入により曝 露を最小限にする取り組みについて紹介する。メチル水 銀は, 食物連鎖を経て, 大型魚へと次第に生物濃縮され る（37）。そのため食物連鎖の上位にいるカジキ，マグ ロなどの大型魚抏よび歯クジラ類は，比較的高濃度のメ チル水銀を含有し，その摂取を介して我々はメチル水銀 に曝露されている。厚生労働省は, 国内に流通している
食品を介した污染物質摂取に関する実態を明らかにする ことを目的として，污染物質摂取量調査を行った。その 調査の結果, 最近 10 年間の水銀の推定 1 日摂取量は平 均 $8.4 \mu \mathrm{g} /$ 人/日で，その流とんどが魚介類由来である ことが分かった（38）。また，柳沼らは日本の妊娠女性 を対象に食物頻度摂取量調査 (FFQ) の実施とともに 13 項目の魚介類摂取量を調査し, 推定メチル水銀摂取 量は $42.3 \mu \mathrm{g} / \mathrm{week}(6.0 \mu \mathrm{g} / \mathrm{day})$ と算出され, そのらち $43 \%$ がマグロやカジキといった大型魚であったと報告 している(39)。こらいった背景から, メチル水銀の曝 露を低減するには, 大型魚の摂取量や頻度を控えるよう な情報提供が効果的と考兄られる。その一方で, メチル 水銀の曝露を気にして魚食を避けるといら食行動は, 魚食でしか得られないdocosahexaenoic acid（DHA）や eicosapentaenoic acid（EPA）などの不飽和多価脂肪酸な ぞの栄養素が不足する可能性もある（リスクのトレード オフ)。Oken らは, 妊娠 $12 \sim 22$ 週の女性に, メチル 水銀濃度の低い魚及び DHA を多く含む魚に関して情報 提供するランダム化比較介入研究を実施した (40)。対 照群，魚摂取に関する情報提供をする群および情報提 供十謝礼を渡す群の 3 群を設定した。その結果, 対照 群と比較し, 情報提供する群および情報提供十謝礼を 渡す群に扔いて，魚食による水銀の掑取量を増やさず に, DHA 摂取量の増加が久られたといら介入の効果を 報告した。さらに，情報提供十謝礼を渡す群でその介入 効果がより顕著であったと報告した。Kirkらも妊娠女 性を対象に，魚摂取に関する情報提供を行ら介入調査を 実施し，3 月月で平均毛髪中水銀濃度が $21 \%$ 減少した と報告した (41)。メチル水銀の場合, 最も影響が懸念 される時期は胎児期である (21)。単に魚食を避けるだ けでなく，曝露リスクを最小限にすると共に，必要な栄 養素をバランスよく摂取するといら情報提供型介入研究 は, 曝露源が明らかな物質については重要な研究スタイ ルとなりらる。
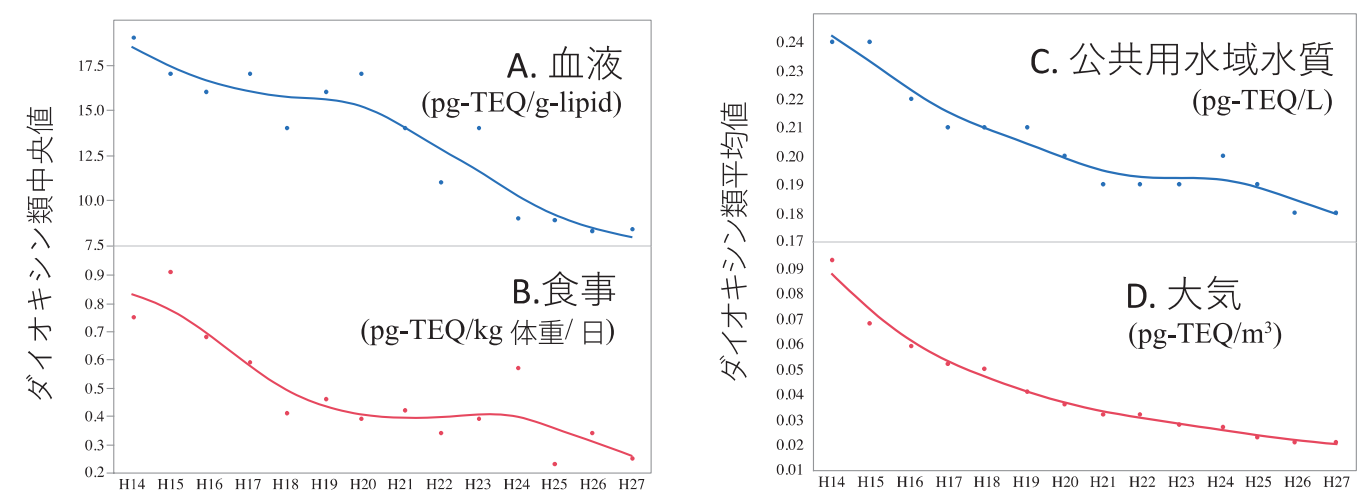

図 4 年度ごとの総ダイオキシン濃度推移に対する近似曲線（A：ヒト血中ダイオキシン類濃度中央值, B : 食事由来ダイオキシン 類摂取量中央値, $\mathrm{C}:$ 公共用水域水質濃度平均値, D : 大気中ダイオキシン類濃度平均值)。引用: 環境省平成 14 年から平成 27 年ま での日本人に扔ける化学物質曝露調査（A 抢よびB）http://www.env.go.jp/chemi/dioxin/pamph/cd/2017ja_full.pdf (35), 環境省環境調査 平成 27 年度報告（C 抢よび D) https://www.env.go.jp/press/103804.html (36) 


\section{5. 結 語}

出生コホート調査に関する論文発表の増加とともに曝 露に関する論文数も増加していた。このことは, 様々な 曝露が子どもの健康に影響を与えることへの懸念と考え られた。一方で，環境政策によって曝露レベルを下げる ことができた鉛やダイオキシンの事例や，曝露源を特定 して体内レベルを低下させることができた介入研究の取 り組みは，今後のリスクコントロールを検討する上で重 要と考えられた。現在進行中の出生コホート調査（小さ なものから大きなものまで含めて）を通して，次の世代 の未来を見据え, 子どもにとって良い環境に関する科学 的な知見の集積が必要である。

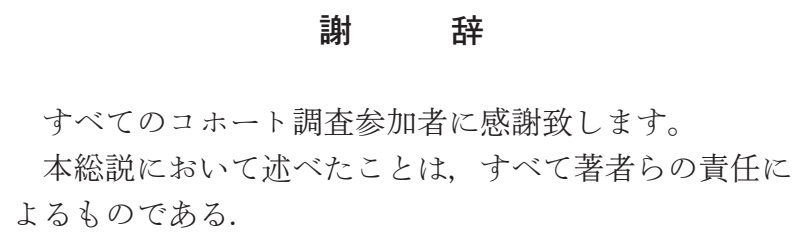

\section{文献}

（1）中山祥嗣, 磯部友彦, 岩井美幸, 小林弥生, 小栗朋子, 竹内文乃. エコチル調査に抢ける化学物質曝露評価. 日本衛生学雑誌 2018;73(2):156-163.

( 2 ) Bach CC, Vested A, Jorgensen KT, Bonde JP, Henriksen TB, Toft G. Perfluoroalkyl and polyfluoroalkyl substances and measures of human fertility: a systematic review. Crit Rev Toxicol 2016;46(9):735-755.

( 3 ) Ferguson KK, O'Neill MS, Meeker JD. Environmental contaminant exposures and preterm birth: a comprehensive review. J Toxicol Environ Health B Crit Rev 2013;16(2):69-113.

( 4 ) Nieuwenhuijsen MJ, Dadvand P, Grellier J, Martinez D, Vrijheid M. Environmental risk factors of pregnancy outcomes: a summary of recent meta-analyses of epidemiological studies. Environ Health 2013;12:6.

( 5 ) Wigle DT, Arbuckle TE, Turner MC, Berube A, Yang QY, Liu SL, et al. Epidemiologic evidence of relationships between reproductive and child health outcomes and environmental chemical contaminants. J Toxicol Env Heal B 2008;11(5-6):373-517.

( 6 ) Chen EK, Zmirou-Navier D, Padilla C, Deguen S. Effects of air pollution on the risk of congenital anomalies: a systematic review and meta-analysis. Int J Environ Res Public Health 2014;11(8):7642-7668.

( 7 ) Nicoletti D, Appel LD, Siedersberger Neto P, Guimaraes GW, Zhang L. Maternal smoking during pregnancy and birth defects in children: a systematic review with metaanalysis. Cad Saude Publica 2014;30(12):2491-2529.

( 8 ) Bach CC, Bech BH, Brix N, Nohr EA, Bonde JP, Henriksen TB. Perfluoroalkyl and polyfluoroalkyl sub- stances and human fetal growth: a systematic review. Crit Rev Toxicol 2015;45(1):53-67.

( 9 ) El Majidi N, Bouchard M, Gosselin NH, Carrier G. Relationship between prenatal exposure to polychlorinated biphenyls and birth weight: A systematic analysis of published epidemiological studies through a standardization of biomonitoring data. Regul Toxicol Pharm 2012;64(1): 161-176.

(10) Grandjean P, Landrigan PJ. Neurobehavioural effects of developmental toxicity. Lancet Neurol 2014;13(3):330 338.

( 11 ) Kabir ER, Rahman MS, Rahman I. A review on endocrine disruptors and their possible impacts on human health. Environ Toxicol Pharmacol 2015;40(1):241-258.

（12）仲井邦彦, 龍田 希. 化学物質ばく露とヒト出生性 比. 臨床環境医学 2016;25 (1):9-14.

( 13 ) Landrigan PJ, Fuller R, Acosta NJR, Adeyi O, Arnold R, Basu NN, et al. The Lancet Commission on pollution and health. Lancet 2018;391(10119):462-512.

( 14 ) Laakso M, Bjork BC. Anatomy of open access publishing: a study of longitudinal development and internal structure. BMC Med 2012;10:124.

( 15 ) Kawamoto T, Nitta H, Murata K, Toda E, Tsukamoto N, Hasegawa $M$, et al. Rationale and study design of the Japan environment and children's study (JECS). BMC Public Health 2014;14:25.

( 16 ) Kishi R, Araki A, Minatoya M, Hanaoka T, Miyashita C, Itoh S, et al. The Hokkaido Birth Cohort Study on Environment and Children's Health: cohort profile-updated 2017. Environ Health Prev Med 2017;22(1):46.

( 17 ) Kishi R, Zhang JJ, Ha EH, Chen PC, Tian Y, Xia Y, et al. Birth Cohort Consortium of Asia: Current and Future Perspectives. Epidemiology 2017;28 Suppl 1:S19-S34.

( 18 ) Nakai K, Suzuki K, Oka T, Murata K, Sakamoto M, Okamura K, et al. The Tohoku Study of Child Development: A cohort study of effects of perinatal exposures to methylmercury and environmentally persistent organic pollutants on neurobehavioral development in Japanese children. Tohoku J Exp Med 2004;202(3):227-237.

( 19 ) Suzuki K, Nakai K, Sugawara T, Nakamura T, Ohba T, Shimada M, et al. Neurobehavioral effects of prenatal exposure to methylmercury and PCBs, and seafood intake: neonatal behavioral assessment scale results of Tohoku study of child development. Environ Res 2010;110(7): 699-704.

( 20 ) Tatsuta N, Murata K, Iwai-Shimada M, Yaginuma-Sakurai K, Satoh H, Nakai K. Psychomotor Ability in Children Prenatally Exposed to Methylmercury: The 18-Month Follow-Up of Tohoku Study of Child Development. Tohoku J Exp Med 2017;242(1):1-8.

(21) National Research Council. Toxicological effects of Methylmercury. Washington, DC: National Academy Press, 2000.

( 22 ) Tuinstra LG, Traag WA, van Rhijn JA, vd Spreng PF. The Dutch PCB/Dioxin Study. Development of a method for the determination of dioxins, planar and other PCBs in human milk. Chemosphere 1994;29(9-11):1859-1875. 
( 23 ) Stewart PW, Reihman J, Lonky EI, Darvill TJ, Pagano J. Cognitive development in preschool children prenatally exposed to PCBs and MeHg. Neurotoxicol Teratol 2003; 25(1):11-22.

(24) Jacobson JL, Jacobson SW. Dose-response in perinatal exposure to polychlorinated biphenyls (PCBs): the Michigan and North Carolina cohort studies. Toxicol Ind Health 1996;12(3-4):435-445.

(25) Mushak P. New directions in the toxicokinetics of human lead exposure. Neurotoxicology 1993;14(2-3):29-42.

(26) Cantonwine D, Hu H, Tellez-Rojo MM, Sanchez BN, Lamadrid-Figueroa $\mathrm{H}$, Ettinger AS, et al. HFE gene variants modify the association between maternal lead burden and infant birthweight: a prospective birth cohort study in Mexico City, Mexico. Environ Health 2010;9:43.

(27) Hornung RW, Lanphear BP, Dietrich KN. Age of Greatest Susceptibility to Childhood Lead Exposure: A New Statistical Approach. Environ Health Perspect 2009;117(8): 1309-1312.

(28) Magnus P, Birke C, Vejrup K, Haugan A, Alsaker E, Daltveit AK, et al. Cohort Profile Update: The Norwegian Mother and Child Cohort Study (MoBa). Int J Epidemiol 2016;45(2):382-388.

(29) Olsen J, Melbye M, Olsen SF, Sorensen TIA, Aaby P, Andersen AMN, et al. The Danish National Birth Cohort - its background, structure and aim. Scand J Public Health 2001;29(4):300-307.

( 30 ) Lin MF, Lucas HC, Shmueli G. Too Big to Fail: Large Samples and the p-Value Problem. Inform Syst Res 2013; 24(4):906-917.

( 31 ) Bellinger DC. A strategy for comparing the contributions of environmental chemicals and other risk factors to neurodevelopment of children. Environ Health Perspect 2012;120(4):501-507.

(32) Reuben A, Caspi A, Belsky DW, Broadbent J, Harrington $\mathrm{H}$, Sugden K, et al. Association of Childhood Blood Lead Levels With Cognitive Function and Socioeconomic Status at Age 38 Years and With IQ Change and Socioeconomic Mobility Between Childhood and Adulthood. JAMA 2017;317(12):1244-1251.

（33）食品安全委員会. 鉛に関する食品健康影響につい て一次報告. 2012. http://www.fsc.go.jp/fsciis/meeting Material/show/kai20120322ka1 (2019.1.31)

(34) 産業技術総合研究所. 鉛リスク評価書 (暫定版). https://unit.aist.go.jp/riss/crm/mainmenu/zantei_0.4/ $\mathrm{Pb}$ 0.4.pdf (2019.1.31)

（35）環境省. 日本人に打ける化学物質ばく露量について. 2017. http://www.env.go.jp/chemi/dioxin/pamph/cd/ 2017ja_full.pdf (2019.1.31)

（36）環境省. 平成 27 年度ダイオキシン類に係る環境調査 結果について. 2017. https://www.env.go.jp/press/files/ jp/105365.pdf (2019.1.31)

（37）島田 美, 佐藤 洋. 水銀. 系川嘉則 (編). ミネ ラルの科学と最新応用技術. 特殊ミネラルの機能. 東京: 株式会社シーエムシー出版, 2008, 349-358.

（38）渡邊敬浩, 堤 智昭, 片岡洋平, 天倉吉章, 畋山智 香子，松田りえ子．食品を介したダイオキシン類等
有害物質摂取量の評価とその手法開発に関する研 究: 国立医薬品食品衛生研究所. 2015. https://mhlwgrants.niph.go.jp/niph/search/NIDD00.do?resrchNum= 201522007A (2019.1.31)

(39) Yaginuma-Sakurai K, Shimada M, Ohba T, Nakai K, Suzuki K, Kurokawa N, et al. Assessment of exposure to methylmercury in pregnant Japanese women by FFQ. Public Health Nutr 2009;12(12):2352-2358.

( 40 ) Oken E, Guthrie LB, Bloomingdale A, Platek DN, Price S, Haines J, et al. A pilot randomized controlled trial to promote healthful fish consumption during pregnancy: The Food for Thought Study. Nutr J 2013;12:33.

(41) Kirk LE, Jorgensen JS, Nielsen F, Grandjean P. Public health benefits of hair-mercury analysis and dietary advice in lowering methylmercury exposure in pregnant women. Scand J Public Health 2017;45(4):444-451.

（42）岸玲子，荒木敦子，宮下ちひろ，伊藤佐智子，湊 屋街子，小林澄貴，他. 2 万人規模の出生コーホー トと，500人規模の小コーホートからなる北海道ス タディが目指してきたもの：環境と子どもの健康一 先天異常・発達・アレルギーの 15 年に拈よぶ経験と 成果一. 日本衛生学雑誌 2018;73(2):164-177.

(43) Fergusson DM, Horwood LJ, Lynskey MT. Early dentine lead levels and subsequent cognitive and behavioural development. J Child Psychol Psychiatry 1993;34(2):215227.

( 44 ) Tong S, Baghurst P, McMichael A, Sawyer M, Mudge J. Lifetime exposure to environmental lead and children's intelligence at 11-13 years: The Port Pirie cohort study. Br Med J 1996;312(7046):1569-1575.

(45) Dietrich KN, Berger OG, Succop PA, Hammond PB, Bornschein RL. The developmental consequences of low to moderate prenatal and postnatal lead-exposure-intellectual attainment in the Cincinnati Lead Study Cohort following school entry. Neurotoxicol Teratol 1993;15(1):3744.

( 46 ) Riojas-Rodriguez H, Solis-Vivanco R, Schilmann A, Montes S, Rodriguez S, Rios C, et al. Intellectual function in Mexican children living in a mining area and environmentally exposed to manganese. Environ Health Perspect 2010;118(10):1465-1470.

( 47 ) Bouchard MF, Sauve S, Barbeau B, Legrand M, Brodeur ME, Bouffard T, et al. Intellectual impairment in schoolage children exposed to manganese from drinking water. Environ Health Perspect 2011;119(1):138-143.

( 48 ) Khan K, Factor-Litvak P, Wasserman GA, Liu X, Ahmed E, Parvez F, et al. Manganese exposure from drinking water and children's classroom behavior in Bangladesh. Environ Health Perspect 2011;119(10):1501-1506.

( 49 ) Oulhote Y, Mergler D, Barbeau B, Bellinger DC, Bouffard T, Brodeur ME, et al. Neurobehavioral function in schoolage children exposed to manganese in drinking water. Environ Health Perspect 2014;122(12):1343-1350.

( 50 ) Chung SE, Cheong HK, Ha EH, Kim BN, Ha M, Kim Y, et al. Maternal Blood Manganese and Early Neurodevelopment: The Mothers and Children's Environmental Health (MOCEH) Study. Environ Health Perspect 2015; 
123(7):717-722.

( 51 ) Haynes EN, Sucharew H, Kuhnell P, Alden J, Barnas M, Wright RO, et al. Manganese Exposure and Neurocognitive Outcomes in Rural School-Age Children: The Communities Actively Researching Exposure Study (Ohio, USA). Environ Health Perspect 2015;123(10):1066-1071.

( 52 ) Agay-Shay K, Martinez D, Valvi D, Garcia-Esteban R, Basagana X, Robinson O, et al. Exposure to EndocrineDisrupting Chemicals during Pregnancy and Weight at 7 Years of Age: A Multi-pollutant Approach. Environ Health Perspect 2015;123(10):1030-1037.

( 53 ) Boucher O, Burden MJ, Muckle G, Saint-Amour D, Ayotte P, Dewailly E, et al. Response inhibition and error monitoring during a visual go/no-go task in inuit children exposed to lead, polychlorinated biphenyls, and methylmercury. Environ Health Perspect 2012;120(4):608-615.

(54) Boucher O, Jacobson SW, Plusquellec P, Dewailly E, Ayotte P, Forget-Dubois N, et al. Prenatal methylmercury, postnatal lead exposure, and evidence of attention deficit/ hyperactivity disorder among Inuit children in Arctic Quebec. Environ Health Perspect 2012;120(10):14561461.

( 55 ) Grandjean P, Poulsen LK, Heilmann C, Steuerwald U, Weihe P. Allergy and sensitization during childhood associated with prenatal and lactational exposure to marine pollutants. Environ Health Perspect 2010;118(10):1429 1433.

( 56 ) Hansen S, Strom M, Olsen SF, Maslova E, Rantakokko P, Kiviranta $\mathrm{H}$, et al. Maternal concentrations of persistent organochlorine pollutants and the risk of asthma in offspring: results from a prospective cohort with 20 years of follow-up. Environ Health Perspect 2014;122(1):93-99.

( 57 ) Heilmann C, Budtz-Jorgensen E, Nielsen F, Heinzow B, Weihe P, Grandjean P. Serum concentrations of antibodies against vaccine toxoids in children exposed perinatally to immunotoxicants. Environ Health Perspect 2010;118(10): 1434-1438.

( 58 ) Jusko TA, De Roos AJ, Lee SY, Thevenet-Morrison K, Schwartz SM, Verner MA, et al. A Birth Cohort Study of Maternal and Infant Serum PCB-153 and DDE Concentrations and Responses to Infant Tuberculosis Vaccination. Environ Health Perspect 2016;124(6):813-821.

( 59 ) Jusko TA, Sisto R, Iosif AM, Moleti A, Wimmerova S, Lancz K, et al. Prenatal and Postnatal Serum PCB Concentrations and Cochlear Function in Children at 45 Months of Age. Environ Health Perspect 2014;122(11): 1246-1252.

( 60 ) Jusko TA, Sonneborn D, Palkovicova L, Kocan A, Drobna B, Trnovec T, et al. Pre- and postnatal polychlorinated biphenyl concentrations and longitudinal measures of thymus volume in infants. Environ Health Perspect 2012; 120(4):595-600.

(61) Orenstein ST, Thurston SW, Bellinger DC, Schwartz JD, Amarasiriwardena CJ, Altshul LM, et al. Prenatal organochlorine and methylmercury exposure and memory and learning in school-age children in communities near the New Bedford Harbor Superfund site, Massachusetts.
Environ Health Perspect 2014;122(11):1253-1259.

(62) Sagiv SK, Thurston SW, Bellinger DC, Altshul LM, Korrick SA. Neuropsychological Measures of Attention and Impulse Control among 8-Year-Old Children Exposed Prenatally to Organochlorines. Environ Health Perspect 2012;120(6):904-909.

(63) Valvi D, Mendez MA, Martinez D, Grimalt JO, Torrent M, Sunyer J, et al. Prenatal concentrations of polychlorinated biphenyls, DDE, and DDT and overweight in children: a prospective birth cohort study. Environ Health Perspect 2012;120(3):451-457.

( 64 ) Chen AM, Yolton K, Rauch SA, Webster GM, Hornung R, Sjodin A, et al. Prenatal Polybrominated Diphenyl Ether Exposures and Neurodevelopment in U.S. Children through 5 Years of Age: The HOME Study. Environ Health Perspect 2014;122(8):856-862.

( 65 ) Chevrier J, Harley KG, Bradman A, Gharbi M, Sjodin A, Eskenazi B. Polybrominated diphenyl ether (PBDE) flame retardants and thyroid hormone during pregnancy. Environ Health Perspect 2010;118(10):1444-1449.

( 66 ) Erkin-Cakmak A, Harley KG, Chevrier J, Bradman A, Kogut K, Huen K, et al. In Utero and Childhood Polybrominated Diphenyl Ether Exposures and Body Mass at Age 7 Years: The CHAMACOS Study. Environ Health Perspect 2015;123(6):636-642.

( 67 ) Eskenazi B, Chevrier J, Rauch SA, Kogut K, Harley KG, Johnson C, et al. In Utero and Childhood Polybrominated Diphenyl Ether (PBDE) Exposures and Neurodevelopment in the CHAMACOS Study. Environ Health Perspect 2013;121(2):257-262.

(68) Gascon M, Fort M, Martinez D, Carsin AE, Forns J, Grimalt JO, et al. Polybrominated Diphenyl Ethers (PBDEs) in Breast Milk and Neuropsychological Development in Infants. Environ Health Perspect 2012;120(12): 1760-1765.

(69) Harley KG, Marks AR, Chevrier J, Bradman A, Sjodin A, Eskenazi B. PBDE concentrations in women's serum and fecundability. Environ Health Perspect 2010;118(5):699704.

( 70 ) Herbstman JB, Sjodin A, Kurzon M, Lederman SA, Jones RS, Rauh V, et al. Prenatal exposure to PBDEs and neurodevelopment. Environ Health Perspect 2010;118(5): 712-719.

(71) Hoffman K, Adgent M, Goldman BD, Sjodin A, Daniels JL. Lactational Exposure to Polybrominated Diphenyl Ethers and Its Relation to Social and Emotional Development among Toddlers. Environ Health Perspect 2012; 120(10):1438-1442.

( 72 ) Makey CM, McClean MD, Braverman LE, Pearce EN, He $\mathrm{XM}$, Sjodin A, et al. Polybrominated Diphenyl Ether Exposure and Thyroid Function Tests in North American Adults. Environ Health Perspect 2016;124(4):420-425.

( 73 ) Vuong AM, Webster GM, Romano ME, Braun JM, Zoeller RT, Hoofnagle AN, et al. Maternal Polybrominated Diphenyl Ether (PBDE) Exposure and Thyroid Hormones in Maternal and Cord Sera: The HOME Study, Cincinnati, USA. Environ Health Perspect 2015;123(10):1079-1085. 
( 74 ) Ward MH, Colt JS, Deziel NC, Whitehead TP, Reynolds P, Gunier RB, et al. Residential Levels of Polybrominated Diphenyl Ethers and Risk of Childhood Acute Lymphoblastic Leukemia in California. Environ Health Perspect 2014;122(10):1110-1116.

( 75 ) Windham GC, Pinney SM, Voss RW, Sjodin A, Biro FM, Greenspan LC, et al. Brominated Flame Retardants and Other Persistent Organohalogenated Compounds in Relation to Timing of Puberty in a Longitudinal Study of Girls. Environ Health Perspect 2015;123(10):1046-1052.

( 76 ) Cupul-Uicab LA, Klebanoff MA, Brock JW, Longnecker MP. Prenatal exposure to persistent organochlorines and childhood obesity in the US collaborative perinatal project. Environ Health Perspect 2013;121(9):1103-1109.

( 77 ) Iszatt N, Stigum H, Verner MA, White RA, Govarts E, Murinova LP, et al. Prenatal and Postnatal Exposure to Persistent Organic Pollutants and Infant Growth: A Pooled Analysis of Seven European Birth Cohorts. Environ Health Perspect 2015;123(7):730-736.

( 78 ) Mendez MA, Garcia-Esteban R, Guxens M, Vrijheid M, Kogevinas M, Goni F, et al. Prenatal Organochlorine Compound Exposure, Rapid Weight Gain, and Overweight in Infancy. Environ Health Perspect 2011;119(2):272-278.

( 79 ) Merrill ML, Cirillo PM, Terry MB, Krigbaum NY, Flom JD, Cohn BA. Prenatal Exposure to the Pesticide DDT and Hypertension Diagnosed in Women before Age 50: A Longitudinal Birth Cohort Study. Environ Health Perspect 2013;121(5):594-599.

( 80 ) Robledo CA, Yeung E, Mendola P, Sundaram R, Maisog J, Sweeney AM, et al. Preconception Maternal and Paternal Exposure to Persistent Organic Pollutants and Birth Size: The LIFE Study. Environ Health Perspect 2015;123(1): $88-94$.

( 81 ) Torres-Sanchez L, Schnaas L, Rothenberg SJ, Cebrian ME, Osorio-Valencia E, Hernandez MD, et al. Prenatal p,p'-DDE Exposure and Neurodevelopment among Children 3.5-5 Years of Age. Environ Health Perspect 2013;121(2):263-268.

( 82 ) Valvi D, Mendez MA, Martinez D, Grimalt JO, Torrent M, Sunyer J, et al. Prenatal Concentrations of Polychlorinated Biphenyls, DDE, and DDT and Overweight in Children: A Prospective Birth Cohort Study. Environ Health Perspect 2012;120(3):451-457.

( 83 ) Warner M, Schall RA, Harley KG, Bradman A, Barr D, Eskenazi B. In Utero DDT and DDE Exposure and Obesity Status of 7-Year-Old Mexican-American Children in the CHAMACOS Cohort. Environ Health Perspect 2013; 121(5):631-636.

( 84 ) Dong GH, Tung KY, Tsai CH, Liu MM, Wang D, Liu W, et al. Serum Polyfluoroalkyl Concentrations, Asthma Outcomes, and Immunological Markers in a Case-Control Study of Taiwanese Children. Environ Health Perspect 2013;121(4):507-513.

( 85 ) Halldorsson TI, Rytter D, Haug LS, Bech BH, Danielsen I, Becher G, et al. Prenatal Exposure to Perfluorooctanoate and Risk of Overweight at 20 Years of Age: A Prospective Cohort Study. Environ Health Perspect 2012;120(5):668-
673

( 86 ) Hoffman K, Webster TF, Weisskopf MG, Weinberg J, Vieira VM. Exposure to Polyfluoroalkyl Chemicals and Attention Deficit/Hyperactivity Disorder in U.S. Children 12-15 Years of Age. Environ Health Perspect 2010; 118(12):1762-1767.

( 87 ) Hoyer BB, Ramlau-Hansen CH, Vrijheid M, Valvi D, Pedersen HS, Zviezdai V, et al. Anthropometry in 5- to 9-Year-Old Greenlandic and Ukrainian Children in Relation to Prenatal Exposure to Perfluorinated Alkyl Substances. Environ Health Perspect 2015;123(8):841-846.

( 88 ) Humblet O, Diaz-Ramirez LG, Balmes JR, Pinney SM, Hiatt RA. Perfluoroalkyl Chemicals and Asthma among Children 12-19 Years of Age: NHANES (1999-2008). Environ Health Perspect 2014;122(10):1129-1133.

(89) Stein CR, Savitz DA. Serum Perfluorinated Compound Concentration and Attention Deficit/Hyperactivity Disorder in Children 5-18 Years of Age. Environ Health Perspect 2011;119(10):1466-1471.

(90) Vested A, Ramlau-Hansen CH, Olsen SF, Bonde JP, Kristensen SL, Halldorsson TI, et al. Associations of in Utero Exposure to Perfluorinated Alkyl Acids with Human Semen Quality and Reproductive Hormones in Adult Men. Environ Health Perspect 2013;121(4):453-458.

( 91 ) Lopez-Espinosa MJ, Mondal D, Armstrong B, Bloom MS, Fletcher T. Thyroid Function and Perfluoroalkyl Acids in Children Living Near a Chemical Plant. Environ Health Perspect 2012;120(7):1036-1041.

( 92 ) Bertelsen RJ, Carlsen KCL, Calafat AM, Hoppin JA, Haland G, Mowinckel P, et al. Urinary Biomarkers for Phthalates Associated with Asthma in Norwegian Children. Environ Health Perspect 2013;121(2):251-256.

( 93 ) Boas M, Frederiksen H, Feldt-Rasmussen U, Skakkebaek NE, Hegedus L, Hilsted L, et al. Childhood Exposure to Phthalates: Associations with Thyroid Function, Insulinlike Growth Factor I, and Growth. Environ Health Perspect 2010;118(10):1458-1464.

( 94 ) Bornehag CG, Carlstedt F, Jonsson BAG, Lindh $\mathrm{CH}$, Jensen TK, Bodin A, et al. Prenatal Phthalate Exposures and Anogenital Distance in Swedish Boys. Environ Health Perspect 2015;123(1):101-107.

( 95 ) Buckley JP, Engel SM, Mendez MA, Richardson DB, Daniels JL, Calafat AM, et al. Prenatal Phthalate Exposures and Childhood Fat Mass in a New York City Cohort. Environ Health Perspect 2016;124(4):507-513.

( 96 ) Cho SC, Bhang SY, Hong YC, Shin MS, Kim BN, Kim JW, et al. Relationship between Environmental Phthalate Exposure and the Intelligence of School-Age Children. Environ Health Perspect 2010;118(7):1027-1032.

( 97 ) Engel SM, Miodovnik A, Canfield RL, Zhu CB, Silva MJ, Calafat AM, et al. Prenatal Phthalate Exposure Is Associated with Childhood Behavior and Executive Functioning. Environ Health Perspect 2010;118(4):565-571.

( 98 ) Hoppin JA, Jaramillo R, London SJ, Bertelsen RJ, Salo PM, Sandler DP, et al. Phthalate Exposure and Allergy in the US Population: Results from NHANES 2005-2006. Environ Health Perspect 2013;121(10):1129-1134. 
( 99 ) Kim Y, Ha EH, Kim EJ, Park H, Ha M, Kim JH, et al. Prenatal Exposure to Phthalates and Infant Development at 6 Months: Prospective Mothers and Children's Environmental Health (MOCEH) Study. Environ Health Perspect 2011;119(10):1495-1500.

(100) Kobrosly RW, Evans S, Miodovnik A, Barrett ES, Thurston SW, Calafat AM, et al. Prenatal Phthalate Exposures and Neurobehavioral Development Scores in Boys and Girls at 6-10 Years of Age. Environ Health Perspect 2014;122(5):521-528.

(101) Lien YJ, Ku HY, Su PH, Chen SJ, Chen HY, Liao PC, et al. Prenatal Exposure to Phthalate Esters and Behavioral Syndromes in Children at 8 Years of Age: Taiwan Maternal and Infant Cohort Study. Environ Health Perspect 2015;123(1):95-100.

(102) Maresca MM, Hoepner LA, Hassoun A, Oberfield SE, Mooney SJ, Calafat AM, et al. Prenatal Exposure to Phthalates and Childhood Body Size in an Urban Cohort. Environ Health Perspect 2016;124(4):514-520.

(103) Trasande L, Attina TM, Sathyanarayana S, Spanier AJ, Blustein J. Race/Ethnicity-Specific Associations of Urinary Phthalates with Childhood Body Mass in a Nationally Representative Sample. Environ Health Perspect 2013; 121(4):501-506.

(104) Valvi D, Casas M, Romaguera D, Monfort N, Ventura R, Martinez D, et al. Prenatal Phthalate Exposure and Childhood Growth and Blood Pressure: Evidence from the Spanish INMA-Sabadell Birth Cohort Study. Environ Health Perspect 2015;123(10):1022-1029.

(105) Whyatt RM, Liu XH, Rauh VA, Calafat AM, Just AC,
Hoepner L, et al. Maternal Prenatal Urinary Phthalate Metabolite Concentrations and Child Mental, Psychomotor, and Behavioral Development at 3 Years of Age. Environ Health Perspect 2012;120(2):290-295.

(106) Whyatt RM, Perzanowski MS, Just AC, Rundle AG, Donohue KM, Calafat AM, et al. Asthma in Inner-City Children at 5-11 Years of Age and Prenatal Exposure to Phthalates: The Columbia Center for Children's Environmental Health Cohort. Environ Health Perspect 2014; 122(10):1141-1146.

(107) Dodge LE, Williams PL, Williams MA, Missmer SA, Toth TL, Calafat AM, et al. Paternal Urinary Concentrations of Parabens and Other Phenols in Relation to Reproductive Outcomes among Couples from a Fertility Clinic. Environ Health Perspect 2015;123(7):665-671.

(108) Meeker JD, Yang T, Ye X, Calafat AM, Hauser R. Urinary concentrations of parabens and serum hormone levels, semen quality parameters, and sperm DNA damage. Environ Health Perspect 2011;119(2):252-257.

(109) Smith KW, Braun JM, Williams PL, Ehrlich S, Correia $\mathrm{KF}$, Calafat AM, et al. Predictors and variability of urinary paraben concentrations in men and women, including before and during pregnancy. Environ Health Perspect 2012;120(11):1538-1543.

(110) Tatsuta N, Kurokawa N, Nakai K, Suzuki K, IwaiShimada M, Murata K, et al. Effects of intrauterine exposures to polychlorinated biphenyls, methylmercury, and lead on birth weight in Japanese male and female newborns. Environ Health Prev Med 2017;22(1):39. 